\title{
Polskie uczelnie wyższe lat międzywojennych i ich społeczności w relacji prasowej „Ilustrowanej Republiki”
}

\begin{abstract}
Polish universities between the world wars and their communities as accounted by the "Ilustrowana Republika" newspaper

"Ilustrowana Republika" was a daily published in Łódź in 1925-1939. Apart from the news, it published economic, social, cultural, educational, and sports information as well as materials on tertiary education. The issue of higher education was raised in over 440 articles and notes, which included information on the Łódź and other Polish universities. Journalists wrote about activities which aimed at making Łódź a university city and about more important events from the life of Polish universities. Fewer publications focused on academic issues; however, a great part of articles showed individual and atypical student conduct sometimes hard to accept such as suicidal attempts, conflicts with the law, organising anti-Semitic manifestations by right-wing students for almost the entire Interwar period. This work does not provide a complete picture of tertiary education or the academic community before WWII as it presents only facts and events described in the newspaper. However, it may be useful as a basic source for more comprehensive works concerning higher education in the past.
\end{abstract}

Keywords: universities, academics, students, "Ilustrowana Republika”, Interwar Poland

Podstawowe zadanie przekazu prasowego sprowadza się do informowania czytelników o najważniejszych wydarzeniach, mających miejsce w kraju i zagranicą. Dobór zamieszczanych treści jest konsekwencją linii programowej przyjętej przez redakcję, stanowiącej zestaw określonych przez nią założeń ideowych i celów. Pryncypia te w poważnej mierze rozstrzygają, które z pozyskanych wiadomości znajdą swój wyraz na łamach gazety, które zaś zostaną pominięte, a także czy wymagają opatrzenia stosownym komentarzem, czy mogą być pozostawione bez jakichkolwiek wyjaśnień. Decydują ponadto o miejscu publikowania poszczególnych tekstów; na pierwszej stronie - w przypadku 
przywiązywania do nich dużej wagi merytorycznej lub na stronach dalszych, kiedy takiego znaczenia im nie przypisywano. Zasady te wyznaczają funkcjonowanie rynku czasopism codziennych nie tylko współcześnie, ale stosowane były również w przeszłości. Kierowała się nimi w pełni „Ilustrowana Republika” - dziennik, ukazujący się w latach 1925-1939 w Łodzi, powołany do życia przez koncern „Republika”. Wśród pięciu jego akcjonariuszy głównym udziałowcem i prezesem był przemysłowiec Maurycy Ignacy Poznański'. Spółka ta należała, obok Pałacu Prasy w Krakowie z Marianem Dąbrowskim na czele, Domu Prasy w Warszawie, założonym przez Henryka Budkiewicza i Antoniego Lewandowskiego, Drukarni Polskiej SA w Poznaniu, prowadzonej przez Romana Leitgebera, do jednego z największych wydawców gazet popularnych w Polsce. Jak podkreśla Wiesław Władyka cechą charakterystyczną wydawców prasy popularnej, zwanej również masową, stanowił fakt, że: Umieli [...] dostosowywać się do wymagań $i$ gustów czytelników, potrafili wykorzystywać koniunkturę polityczna, baczqc uważnie, by jakakolwiek pochopna demonstracja programowa nie odbiła się niekorzystnie na popularnośsi ${ }^{2}$.

Tego typu dzienniki z zasady określające się jako apolityczne, często jednak sympatyzowały lub wspierały akcje propagandowe i stanowiska zajmowane przez większe ugrupowania partyjne. Tak też było w przypadku „Ilustrowanej Republiki”, która nie wiążąc się z żadnym ze stronnictw, przyjęła przychylne stanowisko po przewrocie majowym, wobec obozu rządzącego, co przejawiało się brakiem krytyki, a czasami pochlebnymi opiniami wyrażanymi na temat bieżących posunięć władz centralnych ${ }^{3}$. Bezpośredni jej twórcy: Marian Nusbaum-Ostaszewski - redaktor naczelny dziennika wraz z Leszkiem Kirkienem, zajmującym się działem gospodarczym i Władysławem Polakiem, odpowiedzialnym za sprawy miejscowe, stworzyli pismo adresowane głównie do bogatszych sfer mieszkańców Łodzi, mające zapewnić swoim czytelnikom szybki dostęp do wiadomości politycznych, gospodarczych, społecznych, oświatowych, kulturalnych i sportowych, tak w skali międzynarodowej, krajowej, jak i lokalnej. Ze szczególną troską odnosili się do problemów biedy w mieście spowodowanej wielkim kryzysem ekonomicznym lat trzydziestych, kondycji tutejszego szkolnictwa, sytuacji nauczycieli i uczniów ${ }^{4}$ oraz wszelkich zagadnień dotyczących uczelni wyższych. Należy wspomnieć, że w tym ostatnim przypadku w ciągu 15 lat istnienia gazety na jej łamach ukazało się przeszło 440 artykułów i wzmianek na ich temat.

${ }^{1}$ A. Paczkowski, Prasa polska w latach 1918-1939, Warszawa 1980, s. 167-169; W. Władyka, Prasa Drugiej Rzeczypospolitej, w: J. Łojek, J. Myśliński, W. Władyka, Dzieje prasy polskiej, Warszawa 1988, s. 111-114; M. Hrycek, Stosunki w łódzkiej prasie okresu międzywojennego. Polemika prasowa na łamach tódzkich dzienników na przykładzie „, Głosu Polskiego” i koncernu Republiki, „Folia Litteraria Polonica” 2011, nr 1, s. 10-11; Przegląd prasy tódzkiej, „Ilustrowana Encyklopedia Historii Łodzi”, br. r. wyd. nr 9, s. 269.

2 W. Władyka, op. cit., s. 111.

3 Por. np. A. Paczkowski, op. cit., s. 169.

${ }^{4}$ Zob. np. I. Michalska, Życie łódzkich rodzin w czasach kryzysu ekonomicznego lat trzydziestych XX wieku w przekazie gazety „Ilustrowana Republika”, „Wychowanie w Rodzinie” 2016, nr 2, t. XIV, s. 195-208; eadem, Sprawy szkolnictwa nauczycieli i uczniów w tódzkim dzienniku „Ilustrowana Republika” w latach 1925-1939, „Przegląd Historyczno-Oświatowy” 2017, nr 3-4, s. 150-168. 
Wątkiem szczególnie bliskim „Ilustrowanej Republice” była sprawa powstawania w Łodzi wyższych uczelni. Każdą, nawet najmniejszą pogłoskę na ten temat skrzętnie odnotowywano. W maju 1928 r. ze smutkiem donoszono, że wniosek złożony do Sejmu RP przez posła PSL ,Wyzwolenie” Antoniego Langera o przyznanie dotacji na założenie politechniki został większością głosów odrzucony przez Komisję Budżetową. Pięć miesięcy później, z podobnym skutkiem wystąpił w tej kwestii Komitet Wykonawczy Obchodu 10. Rocznicy Niepodległości, w skład którego weszli, m.in. zastępca wojewody, prezydent miasta, kurator oświaty oraz przedstawiciele Kościoła katolickiego, protestanckiego i gminy żydowskiej. Przyjął on uchwałę wskazującą, że trwałym wkładem upamiętniającym odzyskanie państwowości polskiej powinno być założenie w Łodzi wyższego zakładu naukowego. Nie rozstrzygając jednoznacznie typu oczekiwanej uczelni - uniwersytetu czy politechniki, zadeklarowano, że wszelkie starania zostaną podjęte bezzwłocznie, jeszcze przed 11 listopada. Gazeta relacjonując to wydarzenie, w komentarzu własnym dowodziła: Odnośnie charakteru uczelni - nie ulega dla nikogo watpliwości, że decyzja powinna wypaść na korzyść politechniki. Tylko bowiem wyższa uczelnia techniczna odpowiada potrzebom wielkiego ośrodka przemysłowego ${ }^{6}$. „Ilustrowana Republika" raz jeszcze w 1931 r. powróciła do sprawy konieczności ulokowania politechniki w Łodzi, przypominając, że jej plan opracowany już w 1864 r. bliski był wykonania w następnych latach. Wyznaczona została wówczas działka pod budowę gmachu i rozstrzygnięto konkurs na jego projekt. Wynajęto tymczasowy budynek, przystosowując go do potrzeb naukowych, urządzono laboratorium chemiczne, zakupiono niezbędną aparaturę badawczą, zgromadzono odpowiedni księgozbiór. Z trudem wypracowany statut przewidywał 4-letnie studia na wydziałach inżynierii cywilnej, górniczej i mechaniczno-technologicznej oraz zakładał powołanie 12 katedr profesorskich. Kiedy projekt całego przedsięwzięcia znalazł się w Petersburgu w celu ostatecznego zatwierdzenia, władze centralne Rosji wstrzymały go z przyczyn politycznych i gospodarczych, w obawie przed dużym skupiskiem studentów w środowisku robotniczym oraz niechęcią do szerzenia oświaty i rozwoju konkurencyjnego przemysłu na terenie Królestwa. Dziennik, przywołując odległą historię łódzkich zmagań o wyższą uczelnię techniczną, ale również odwołując się do tej najbliższej sprzed paru lat w wolnym już kraju, z sarkazmem pisał: Nie miała Łódź politechniki w roku 1865 (38.000 mieszkańców). Nie ma jej i w roku 1931, w 60 lat później (600 000 mieszkańców)7.

Z kolei sukcesem zakończyło się powołanie w Łodzi oddziału Wolnej Wszechnicy Polskiej w Warszawie. Pierwsza wzmianka na ten temat pojawiła się w maju 1928 r., w której informowano o podjęciu przez Magistrat prac zmierzających do założenia

\footnotetext{
5 Eódź nie otrzyma politechniki, „Ilustrowana Republika” (dalej: IR) 1928, nr 131, s. 1.

${ }^{6}$ Wyższa uczelnia $w$ Łodzi zostanie założona dla upamiętnienia wielkiej chwili-odzyskania niepodległości. Uniwersytet, czy politechnika?, IR, 1928, nr 27 [wł. 273], s. 7.

7 Józ. Lit., Projekt politechniki w Lodzi byt już calkowicie opracowany $i$ bliski realizacji w 1864-tym. Dlaczego dotychczas nie uczyniono nic w tym kierunku?, IR, 1931, nr 103, s. 7.
} 
w najbliższym roku akademickim filii wspomnianej prywatnej szkoły wyższej. Specjalnie powołana do tego „grupa robocza" miała nawiązać kontakty z władzami warszawskiej uczelni, kompletować kadrę naukową, zabezpieczyć odpowiedni lokal, zapewnić źródła finansowania. Jeszcze w tym samym miesiącu relacjonowano wizytę rektora WWP w Warszawie Teodora Viewegera w łódzkim Ratuszu, podczas której uzgodniono sprawy natury organizacyjnej i finansowej całego zamierzenia ${ }^{8}$. Wydarzenie to wywołało na łamach prasy dyskusje na temat zasadności wyboru tego typu naukowej placówki. $\mathrm{Z}$ jednej strony pojawiała się tęsknota za uniwersytetem, dodającym prestiżu miastu, z drugiej praktyczne spojrzenie na jego przemysłowy charakter przeważało na korzyść politechniki. W obydwu przypadkach świadomość braku własnych wykładowców studziła wszelkie zapały. $\mathrm{Z}$ żalem, ale i nadzieją przyjmowano prawdę, że oddział Wolnej Wszechnicy musi na razie wystarczyć9.

Poważne zaangażowanie i wielki wysiłek łódzkiej i warszawskiej „strony” przeprowadzającej najpierw udane pertraktacje, a później konkretne działania, spowodowały, że 28 października 1928 r. nastąpiło uroczyste otwarcie uczelni, którą często nazywano „nową odmianą uniwersytetu”. Jak donosiła „Ilustrowana Republika” w obecności przedstawicieli elit kulturalnej Łodzi, miejscowych władz, delegatów stowarzyszeń studenckich ze stolicy i wiceministra Wyznań Religijnych i Oświecenia Publicznego Sławomira Czerwińskiego przemówienie inauguracyjne wygłosił Teodor Vieweger, silnie akcentując konieczność szybkiego odpowiadania przez szkolnictwo akademickie na potrzeby zmieniającej się rzeczywistości. Wyjaśniał: Rola uczelni wyższych staje się coraz bardziej doniosta, gdyż na nich ciązy obowiazek dostarczania spoteczeństwu dostatecznie licznych kadrów pracowników naukowo przygotowanych. Wymaga to oczywiście przystosowania się uczelni do aktualnych zadań, jakie wysuwa życie. Pojęcie uczelni wyższej wzorowane na średniowiecznym uniwersytecie jest nam dalekie. Życie wytwarza dziśs nowe typy uczelni ${ }^{10}$. Spotkanie zakończył wykład z zakresu higieny społecznej przygotowany przez dra Seweryna Sterlinga i odśpiewanie Gaudeamus igitur ${ }^{11}$.

Z informacji prasowych wynika, że łódzka Wszechnica początkowo oferowała naukę na trzech wydziałach - humanistycznym (polonistyka, historia, filozofia), nauk politycznych i społecznych (prawo, ekonomia) oraz pedagogicznym. Wkrótce dołączył do nich wydział matematyczno-przyrodniczy. Pochwalić się mogła uzyskanymi w 1929 r. prawami zrównującymi jej dyplomy z dyplomami uniwersytetów państwowych. Dodatkowo prowadziła Studium Handlowe, głównie przeznaczone dla księgowych. We wczesnych

8 Wolna wszechnica $w$ Lodzi, IR, 1928, nr 132, s. 7; Wolna wszechnica $w$ Lodzi, IR, 1928, nr 141, s. 5; Wszechnica $w$ Lodzi, IR, 1928, nr 173, s. 5; Pierwsza wyższa uczelnia w Łodzi, IR, 1928, nr 184, s. 7.

9 Zob. np. H. P., Ani uniwersytet, ani politechnika!, IR, 1928, nr 1928, nr 275, s. 7; Uniwersytet czy politechnika, IR, 1928, nr 276, s. 7; Jakie względy przemawiają na korzyść założenia w Łodzi uniwersytetu, IR, 1928, nr 276, s. 7.

${ }^{10}$ Historyczna chwila dla Łodzi. Uroczyste otwarcie oddziału Wolnej Wszechnicy, IR, 1928, nr 300, s. 7.

${ }^{11}$ H.P., Mamy uniwersytet $w$ Lodzi, IR, 1928, nr 278, s. 7; Otwarcie wszechnicy w Lodzi, IR, 1928, nr 299, s. 3; Historyczna chwila dla Łodzi. Uroczyste..., s. 7. 
planach było powołanie Studium Kultury Polskiej, a pod koniec lat 30. zmierzano do uruchomienia Wydziału Chemicznego i magisterskich studiów handlowych ${ }^{12}$.

Według relacji „Ilustrowanej Republiki” spora część kadry uczelni w liczbie bliskiej 50, profesorów pochodząca z Warszawy, uzupełniana była miejscowym potencjałem naukowym, zatrudnianym głównie na etatach asystentów lub podejmującym tzw. wykłady zlecone. Podkreślano również, że zdecydowana większość słuchaczy w łódzkiej filii, bo aż 88\% stanowili mieszkańcy Łodzi, reszta wywodziła się z pobliskich okolic ${ }^{13}$. Warto wspomnieć, że sprawa pochodzenia narodowościowego studentów i zasadności istnienia Wolnej Wszechnicy w „ziemi obiecanej” stała się w 1935 r. przedmiotem zainteresowania frakcji Stronnictwa Narodowego, która wystąpiła z wnioskiem na posiedzeniu Rady Miejskiej o skreślenie subwencji w kwocie 100 tys. zł na prowadzenie tej szkoły. W uzasadnieniu wskazywano na zdominowanie uczelni przez słuchaczy-Żydów i na możliwość wyjazdu zainteresowanych kształceniem na poziomie wyższym do innych miast uniwersyteckich. W odpowiedzi na te argumenty gazeta przedstawiła dane liczbowe, z których wynikało, że w uczelni kształcą się przede wszystkim dzieci robotników i pracowników umysłowych, a więc pochodzących ze sfer niezamożnych, niemogących sobie finansowo pozwolić na wysyłanie ich w odległe krańce Polski. W dziesiątą rocznicę powstania łódzkiej Wszechnicy przywołane zostały słowa rektora T. Viewegera kreślącego obraz społeczności studenckiej. Wskazywał, że młodzież akademicka rekrutuje się w 35\% z dzieci pracowników fizycznych, w 26\% - dzieci ze sfer przemysłowo-handlowych, w 18\% dzieci z rodzin pracowników umysłowych, w 14\% - dzieci z rodzin rolniczych, w 7\% $-\mathrm{z}$ innych grup zawodowych, z czego ponad $81 \%$ wszystkich wymienionych wyznawało religie chrześcijańskie ${ }^{14}$.

W pierwszym roku funkcjonowania do WWP w Łodzi zapisanych było ponad 250 słuchaczy, rok później w zajęciach uczestniczyło 345 osób, a w 1932 - przeszło 400. Stosunkowo nieduża ich liczba w porównaniu do stanu studentów uczelni państwowych, w opinii wyrażonej gazecie przez władze rektorskie, wynikała z relatywnie wysokiego czesnego, które wynosiło w początkowych latach nauki w roku akademickim 1928/1929 - 260, a w następnym już 320 zł za rok, zaś w V i VI semestrze studiów wzrastało do 360 zł. W 1932 r. poinformowano, że średnio za rok nauki trzeba zapłacić około 320 zł, a trzy lata później w granicach 280 zł. Z kolei, jak podaje Sławomir Maj we Wszechnicy w Warszawie na Wydziale Matematyczno-Przyrodniczym opłaty te wahały się od 160 do

12 Wolna Wszechnica Polska (reklama), IR, 1932, nr 27, s. 6; 1933, nr 165, s. 2; 1933, nr 204, s. 3, 1933, nr 280, s. 3; 1934, nr 238, s. 3; 1938, nr 242, s. 2; Na Uniwersytecie Łódzkim. Wszechnica łódzka rozwija się bardzo pomyślnie, IR, 1932, nr 163, s. 7; Wyższa uczelnia handlowa zostanie uruchomiona w Łodzi dnia 1 października, IR, 1932, nr 251, s. 7; Łódź posiada uniwersytet, IR, 1934, nr 254, s. 5; 10-lecie Wolnej Wszechnicy w Lodzi, IR, 1938, nr 47, s. 7.

${ }^{13}$ Na Uniwersytecie Łódzkim. Wszechnica ..., s. 7; 10-lecie Wolnej Wszechnicy..., s. 7. Zob. też: Skład osobowy i spis wykładów na rok akademicki 1936/37, Łódź 1936, s. 6-9.

${ }^{14}$ Zamknięcia Wolnej Wszechnicy domagać się będzie frakcja narodowa $w$ radzie miejskiej, IR, 1935, nr 11, s. 5; Prawda o Wolnej Wszechnicy, IR, 1935, nr 87, s. 8; 10-lecie Wolnej Wszechnicy..., s. 7. 
80 zł za semestr, według przyjętej zasady, im wyższy rok studiów, tym mniejsze koszty edukacji15.

Nie posiadając własnego lokalu, łódzka uczelnia wynajmowała pomieszczenia dydaktyczne w budynku szkoły powszechnej przy ul. Dr. Seweryna Sterlinga 24 i w Państwowej Szkole Techniczno-Przemysłowej przy ul Żeromskiego 115. Pod koniec lat 30. redaktorzy „Ilustrowanej Republiki” donosili o rozpoczęciu wznoszenia przez WWP dużego obiektu przy ul. P. O.W, nad wykonaniem którego osobiście czuwał architekt profesor Politechniki Warszawskiej Marian Lalewicz. Działkę na ten cel nieodpłatnie przekazała firma Stiller i Bieleszowski. W dniu 11 grudnia 1937 r. w obecności ministra WRiOP Wojciecha Świętosławskiego został poświecony kamień węgielny pod jego budowę. Oddanie gmachu do użytku z salami wykładowymi, seminaryjnymi, ćwiczeniowymi, pracowniami, biblioteką i biurami, przeznaczonego dla ponad tysiąca studentów, przewidywano w 1939 r. $^{16}$

Z nielicznych notek zamieszczanych w dzienniku wynika, że Wszechnica w Łodzi od czasu do czasu stawała się obiektem krytyki środowisk prawicowych. W związku z tą sytuacją wydrukowano wypowiedź ks. prof. dra Antoniego Roszkowskiego, który stwierdził: Nie wiem skąd powstaty wersje, że jest to uczelnia „masońska”. Jestem księdzem [...] i oświadczam, że nigdzie nie miałem takiej swobody w nauczaniu, jak właśnie w tej $u c z e l n i^{17}$. Dobrego imienia uczelni bronili również studenci, organizując wiec, będący skutkiem odezwy wydanej w lutym 1939 r. przez Komitet Organizacyjny tworzonej wówczas Akademii Lekarskiej, w której informowano mieszkańców, że dzięki tej inicjatywie Łódź stanie się miastem akademickim. W podjętej rezolucji przypominano dzieje Wszechnicy i jej dokonania, a w końcowej części wystąpiono z następującym apelem: Młodzież akademicka Wszechnicy tódzkiej stwierdza stanowczo, że nie dopuści do przemilczenia swej uczelni $i$ występować będzie najenergiczniej przeciwko wszelkim nieuzasadnionym pretensjom i robienia z Łodzi „,nareszcie miasta uniwersyteckiego”, kiedy Łódź od dawna posiada wyższy zakład naukowy, coraz lepiej się rozwijający's.

Pomimo pojawienia się Wolnej Wszechnicy w Łodzi, na łamach „Ilustrowanej Republiki" ukazywały się artykuły, wskazujące że w dalszym ciągu różne środowiska miejscowe domagały się powstawania kolejnych uczelni, które uznawano za niezbędne dla właściwego funkcjonowania miasta. Przemysłowcy już w 1930 r. zauważyli konieczność stworzenia Wyższej Szkoły Włókienniczej lub Wyższej Szkoły Tekstylnej kształcącej inżynierów tkackich i farbiarskich. Kierowali oni w tej sprawie memoriały do Ministerstwa Oświaty i Prezydium Rady Ministrów, oferując jednocześnie konkretną pomoc

${ }^{15}$ H. P., Mamy uniwersytet..., 7; Rozwój Wszechnicy łódzkiej, IR, 1929, nr 170, s. 4; S. Maj, Studia geofizyczne w Wolnej Wszechnicy Polskiej w Warszawie 1918-1939, „Przegląd Geofizyczny” 2013, nr 3-4, s. 222-223; Rozwój Wszechnicy łódzkiej, IR, 1930, nr 241, s. 7.

16 10-lecie Wolnej Wszechnicy..., s. 7; Gmach Wolnej Wszechnicy stanie na placu zaofiarowanym przez f-mę ,, Stiller i Bieleszowski”, IR, 1936, nr 128, s. 9.

17 Ibidem.

18 Protest studentów W.W. P. w Lodzi, IR, 1939, nr 57, s. 7. 
w przypadku pojawienia się pozytywnej decyzji, która jednak nie została podjęta do wybuchu II wojny światowej ${ }^{19}$. Z kolei 7 lat później pomysłodawcą Wyższej Szkoły Handlowej była Izba Przemysłowo-Handlowa, dla której ogólny wzór do naśladowania stanowiła warszawska WSH. Zdecydowano jednak, że powinna uwzględniać łódzkie uwarunkowania i kształcić przede wszystkim przyszłych kierowników przedsiębiorstw przemysłowych i handlowych. Gazeta odnotowywała wszelkie działania komitetu organizacyjnego, mającego doprowadzić do powstania uczelni. Spotykał się on z jednej strony z profesorami WSH w Warszawie w sprawach wypracowania statutu szkoły i rozwiązań programowych, z drugiej z pracownikami ministerstwa WRiOP, a także ministrem W. Świętosławskim w celu uzyskania przychylności władz dla tego projektu. W rezultacie ustalono, że łódzka WSH będzie początkowo placówką prywatną lub społeczną, a po kilku latach zostanie upaństwowiona, natomiast zapewnienie jej wysokiego poziomu nauczania pozwoli na przyznawanie absolwentom tytułów akademickich. W maju $1938 \mathrm{r}$. Komitet Organizacyjny, biorąc pod uwagę czas niezbędny dla uzyskania koncesji, wynajęcia odpowiednich lokali, pozyskania wykładowców i niezbędnych funduszy, przyjął uchwałę, że ostateczne uruchomienie szkoły nastąpi jesienią 1939 r. $^{20}$

Zupełnie inaczej wyglądała sprawa utworzenia w Łodzi Akademii Lekarskiej. „Ilustrowana Republika" na bieżąco relacjonowała toczące się w tej kwestii dyskusje i prowadzone prace przygotowawcze. Z wszystkich publikacji poświęconych powstaniu nowej szkoły wyższej jasno wynika, że to nie sfery tego miasta, ale Ministerstwo WRiOP, Ministerstwo Spraw Wojskowych oraz Ministerstwo Pracy i Opieki Społecznej wystąiły z zamysłem powołania uczelni, której zadaniem miało być kształcenie lekarzy wojskowych. W planach postrzegano ją jako odrębny wydział mającego powstać w przyszłości Uniwersytetu Łódzkiego, edukującego również lekarzy cywilnych. Bezpośrednią przyczyną powzięcia takiego zamiaru był katastrofalny brak medyków na terenie kraju. Podkreślano, że 12660 lekarzy i 1950 felczerów nie jest w stanie zapewnić opieki zdrowotnej ludności w Polsce. Wybór Łodzi podyktowany był dwoma podstawowymi względami: po pierwsze, na terenie miasta istniały wszystkie typy szpitali (m. in. weneryczny, gruźliczy, chirurgiczny, z oddziałami zakaźnymi, łącznie z 2,5 tysiącem łóżek i szpital specjalistyczny, mogący pomieścić 500 umysłowo chorych) niezbędne do odbywania praktyk, po drugie - bliskość od stolicy liczona 1,5-godzinną podróżą pociągiem ułatwiała skompletowanie kadry profesorskiej wywodzącej się z Wydziału Lekarskiego Uniwersytetu Warszawskiego. W początkowej fazie konceptualizacji projektu rozważano założenie Wydziału Lekarskiego przy Wolnej Wszechnicy w Lodzi, jednak ta propozycja została oprotestowana przez warszawskie i krakowskie środowiska medyczne. Następnie zastanawiano się nad uruchomieniem Wojskowej Akademii Lekarskiej lub Wyższego Studium

19 Wyższa szkoła włókiennicza ma powstać w Łodzi w najbliższym czasie, IR, 1930, nr 112, s. 5; Wyższa uczelnia w Łodzi ma powstać, dzięki staraniom przemystu, IR, 1930, nr 238, s. 5.

${ }^{20}$ Akademia Handlowa $w$ Lodzi, IR, 1937, nr 316, s. 5; O Wyższa Uczelnię Handlowa w Łodzi, IR, 1938, nr 98, s. 5; Dwie wyższe uczelnie maja być uruchomione w przyszłym roku szkolnym, IR, 1938, nr 128, s. 8; Wyższa Szkoła Handlowa w Lodzi będzie uruchomiona na jesieni roku 1939, IR, 1938, nr 145, s. 5. 
Lekarskiego, będącego filią Wydziału Lekarskiego Uniwersytetu Warszawskiego. Ostatecznie postanowiono o powołaniu autonomicznej Akademii Lekarskiej. Odzywały się jednak głosy przeciwne, które domagały się otwarcia Wydziału Medycznego w istniejącym już Uniwersytecie w Lublinie, założenia szkoły w Przemyślu ze względu na nieodległe sąsiedztwo z Uniwersytetem Jana Kazimierza we Lwowie lub w jednym z miast Centralnego Okręgu Przemysłowego. Dodatkowy sprzeciw do Ministerstwa Oświaty złożyły uniwersyteckie wydziały lekarskie ze Lwowa, Warszawy i Wilna, domagając się przekazania przeznaczonych dla Łodzi kwot na rozbudowę ich jednostek organizacyjnych. Z kolei na wiecu urządzonym przez Koło Medyków Uniwersytetu Poznańskiego przyjęto rezolucję, w której nie zgadzano się m.in. na łamanie wielowiekowej tradycji urządzania wydziałów lekarskich przy uniwersytetach i wyrażano obawę, że łódzka szkoła nie wyposaży należycie lekarzy w niezbędną wiedzę i umiejętności. Wyłoniony Komitet Obywatelski do tworzenia uczelni wyodrębnił prezydium komitetu wykonawczego i Komisję Finansową, które niezwłocznie przystąpiły do konsultowania z profesorami medycyny merytorycznych rozwiązań funkcjonowania uczelni oraz architektami na temat wykonania projektu gmachu dla nowo powstającej uczelni. Równocześnie zabiegano u władz miejskich o przyspieszenie przekazania 6 hektarów ziemi na Radogoszczu przeznaczonych pod jej budowę. W rezultacie ustalono, że obiekt nowo powstającej szkoły usytuowany zostanie przy ulicy Narutowicza, gdzie w niewielkim oddaleniu miało w przyszłości powstać osiedle uniwersyteckie. Władze centralne przeznaczyły na powstanie budynku 2 miliony zł z zastrzeżeniem, że drugie tyle musi zostać wniesione przez tzw. wkład społeczny. Gazeta, przekazując wiadomości czytelnikom, z niepokojem pisała, że w pewnym momencie istniało zagrożenie wstrzymania wszystkich prac budowlanych ze względu na wydłużający się czas zbiórki pieniężnej wśród łodzian. W kwietniu 1939 r. Ministerstwo Pracy i Opieki Społecznej zaleciło w przyspieszonym w tempie przystąpienie do stawiania obiektu, aby jesienią mogły rozpocząć się w nim zajęcia. Zarząd Komitetu Obywatelskiego zdecydował jednak, że ze względu na krótki czas, jaki pozostał do otwarcia roku akademickiego, wykłady odbywać się będą w wynajmowanych lokalach. Uczelnia miała być finansowana przez rząd oraz miasto, które zobowiązało się przeznaczać 180 tys. zł rocznie na stypendia, w szczególności dla młodzieży robotniczej, która zainteresowana będzie studiami medycznymi w Łodzi. Zgodnie z przyjętymi założeniami uczelnia łódzka miała promować każdego roku 200 lekarzy ${ }^{21}$.

${ }^{21}$ Dwie wyższe uczelnie mają być uruchomione..., s. 8; Wyższa Uczelnia Lekarska ma powstać w Lodzi, IR, 1938, nr 194, s.5; Akademia Lekarska w Lodzi, IR, 1938, nr 196, s. 5; Utworzenie Akademii Lekarskiej, IR 1939, nr 215, s. 5; Akademia Lekarska $w$ Lodzi, IR 1938, nr 204, s. 5; Akademia Lekarska w Lodzi ma być uruchomiona już w przyszłym roku, IR, 1938, nr 247, s. 5; Strajk akademików w Poznaniu, IR, 1938, nr 296, s. 7; Akademia Lekarska w Lodzi powstanie już od następnego roku akademickiego t. j. w październiku 1939 r., IR, 1938, nr 275, s. 5; Budowa uczelni lekarskiej w Lodzi, IR, 1939, nr 70, s. 5; Akademia Lekarska w Lodzi będzie utworzona, IR, 1939, nr 82, s. 6; Budowa Akademii Lekarskiej odroczona, IR, 1939, nr 96, s. 5; Akademia Lekarska w Lodzi będzie utworzona, IR, 1939, nr 108, s. 5; Akademia Lekarska w Lodzi będzie utworzona na razie w budynku wynajętym, IR, 1939, nr 115, s. 5; Osiedle uniwersyteckie w Lodzi, IR, 1939, nr 141, s. 7. 
„Ilustrowana Republika”, choć nie pomijała wydarzeń, jakie miały miejsce w szkołach wyższych w innych miastach, to czyniła to zdecydowanie rzadko. Kilka artykułów i notek poświeciła Uniwersytetowi Warszawskiemu, w pierwszej kolejności przywołując inaugurację roku akademickiego w 1926 r., w której uczestniczyli m.in.: Prezydent RP Ignacy Mościcki, w zastępstwie kardynała Aleksandra Kakowskiego - prałat Aleksander Fajęcki, pierwszy prezes Sądu Najwyższego, rektorzy Politechniki, Wyższej Szkoły Handlowej i Szkoły Głównej Gospodarstwa Wiejskiego, były premier Władysław Grabski, przedstawiciele władz państwowych, samorządowych i wojskowych oraz świata naukowego i studentów. Rektor prof. Stefan Pieńkowski w sprawozdaniu za rok poprzedni nakreślił trudną sytuację finansową uczelni, która zaowocowała uchwałą senatu o nieotwieraniu naboru na rok 1926/1926 w przypadku, kiedy nie ulegnie ona zmianie. Aby zrównoważyć budżet zmuszony został do zwinięcia trzech katedr, zwolnienia sześciu asystentów i czterech osób z personelu administracyjnego ${ }^{22}$. Podawano także krótkie informacje na temat wymagań formalnych związanych z zapisami na Uniwersytet, które wskazywały na konieczność złożenia nie tylko świadectwa dojrzałości, życiorysu, ale także zaświadczenia o niekaralności ${ }^{23}$. W lipcu 1935 r. informowano o mającej nastąpić w najbliższym czasie zmianie nazwy uczelni z Uniwersytetu Warszawskiego na Uniwersytet Warszawski Józefa Piłsudskiego, zaś rok później o poświeceniu nowego gmachu Auditorium Maximum ${ }^{24}$. Dodatkowo skupiono się na wyborach rektora na lata 1936/1937-1938/1939, podczas których kolejno wybrani prof. Stefan Pieńkowski i prof. Franciszek Czubalski odmówili objęcia tego urzędu. W trzeciej turze wyborów stanowisko przyjął prof. Włodzimierz Antoniewicz ${ }^{25}$.

Na łamach łódzkiego dziennika pojawiły się również treści odnoszące się do Szkoły Głównej Gospodarstwa Wiejskiego w Warszawie i Uniwersytetu Poznańskiego. W pierwszym przypadku chodziło o pogłoski zlikwidowania tej uczelni ze względu na istnienie już dostatecznej liczby miejsc kształcenia w Akademii Rolniczej w Dublanach, na stosownych wydziałach w Krakowie, Poznaniu i Wilnie oraz w działających wielu kursach rolniczych, a także powodu zmniejszającej się w dobie kryzysu gospodarczego liczbie kandydatów na tego typu studia oraz kłopotów absolwentów ze znalezieniem odpowiedniej dla nich pracy ${ }^{26}$. W drugim przypadku gazeta relacjonowała uroczystości nadania w 1933 r. Marszałkowi J. Piłsudskiemu przez Senat Uniwersytetu Poznańskiego tytułu doktora honoris causa, zaś w roku 1935 - wręczenie przez rektora ministrowi WRiOP

${ }^{22}$ Wczoraj Uniwersytet Warszawski święcit inaugurację swego dwunastego roku akademickiego, IR, 1926, nr 296, s. 1.

${ }^{23}$ Zapisy na Uniwersytet Warszawski, IR, 1927, nr 232, s. 6.

${ }^{24}$ Nowy Gmach uniwersytecki w Warszawie, IR, 1936 nr 19, s. 2.

${ }_{25}$ Nazwa Uniwersytetu warszawskiego będzie zmieniona $w$ drodze dekretu Prezydenta Rzplitej, IR, 1935, nr 204, s. 4.

${ }^{26}$ „Szkoła Główna Gospodarstwa Wiejskiego” w Warszawie będzie zlikwidowana, IR, 1933, nr 165, s. 2. 
Konstantemu Chylińskiemu dyplomu potwierdzającego tę godność z prośbą o przekazanie go Marszałkowej Piłsudskiej²7.

Podobne jak uczelniami krajowymi, tak i pracownikami szkół wyższych gazeta zajmowała się w niewielkim stopniu. Teksty przywoływały ich różnorodne, czasami kontrowersyjne, czasami odważne, dalekie od oportunizmu czyny i zachowania. Redaktorom pisma nie uszedł uwadze list otwarty zamieszczony w stołecznej prasie przez inżyniera Stanisława Sarnowskiego, zarzucający profesorowi Politechniki Warszawskiej Gustawowi Mokrzyckiemu plagiat, polegający na bezpośrednim wykorzystaniu w swojej książce o lotnictwie dorobku naukowego badaczy zagranicznych. Milczenie i brak wyjaśnień ze strony obwinionego sprowokował reakcję łódzkich dziennikarzy w postaci komentarza: Sadzimy, że ciało profesorskie powinno zabrać głos w tej sprawie i zmusić swego kolege do wyjaśnienia tej wysoce przykrej i kompromitujacej sprawy ${ }^{28}$. Innym razem relacjonowano złożenie aktu oskarżenia przez pacjentkę przeciwko lekarzowi - profesorowi Uniwersytetu Jagiellońskiego - Januaremu Zubrzyckiemu, który, jej zdaniem, po dokonaniu aborcji podyktowanej chorobą serca, wbrew konsylium lekarskiemu i bez zgody zainteresowanej, dokonał, na skutek pojawiających się powikłań, powtórnej operacji, doprowadzając tym do bezpłodności kobiety ${ }^{29}$. Podobnie znalazła swój finał w sądzie sprawa po złożeniu przez studentkę Uniwersytetu Warszawskiego doniesienia do prokuratury na doktora rentgenologii, który zaraził ją chorobą weneryczną, po czym odszedł i zawarł związek małżeński z inną osobą ${ }^{30}$. W jeszcze innym opisywanym przez gazetę procesie stanęli naprzeciwko siebie pracownicy naukowi Uniwersytetu Poznańskiego. Prof. Józef Kostrzewski pozwał prof. Czesława Znamierowskiego o zniesławienie. Sytuacja, która doprowadziła do konfliktu miała miejsce podczas odczytu wygłoszonego na uczelni przez Juliusza Kaden-Bandrowskiego, kiedy to grupa studentów wznoszonymi krzykami i awanturami manifestowała swoje poglądy wobec pisarza. Profesor Znamierowski uznając, że prowodyrem tych zajść był jego uczelniany kolega, dając wyraz swojemu oburzeniu, symbolicznie go spoliczkował. Mimo próśb rektora i sądu grodzkiego o zawarcie ugody, doszło do rozprawy, w wyniku której oskarżony został skazany na trzy dni $\operatorname{aresztu}^{31}$.

O tym, że profesura uczelniana żywo odnosiła się do sytuacji politycznej w Polsce świadczą doniesienia „Ilustrowanej Republiki” prezentowane na pierwszych stronach gazety. W grudniu 1930 r. przedrukowano odezwę wydaną przez pracowników Politechniki Warszawskiej w sprawie wydarzeń w Brześciu podpisaną przez 44 profesorów, 8 docentów i kilkudziesięciu asystentów. Pisali w niej: W życiu państw i narodów są zdarzenia,

\footnotetext{
${ }^{27}$ Marszałek Pitsudski honorowym doktorem Uniwersytetu Poznańskiego, IR, 1933, nr 315, s. 1; Uniwersytet Poznański w hołdzie Wodzowi Narodu, IR, 1935, nr 290, s. 2.

28 Skandal w świecie naukowym, IR, 1928, nr 219, s. 7.

${ }^{29}$ Profesor uniwersytetu $w$ Krakowie oskarżony przez pacjętkę, IR, 1933, nr 203, nr 10.

${ }^{30}$ Romans doktora ze studentka skończyt się przed kratkami sądowymi, IR, 1934, nr 84, s. 5.

31 Profesor uniwersytetu skazany za obrazę swego kolegi, IR, 1930, nr 309, s. 2.
} 
gdy ludzie oddani pracy fachowej i stojacy z dala od polityki milczeć nie moga. Od kilku tygodni cate społeczeństwo wstrzaśnięte jest dogłębnie wiadomościami o niewiarygodnych wykroczeniach popetnianych $w$ stosunku do więźniów brzeskich przez władze administracyjne. [...] zwracamy się w imieniu dobra publicznego i honoru Rzeczypospolitej do czynników miarodajnych, aby zechciaty jak najprędzej sprawę tę zbadać, śledztwo wdrożyć $i$ winnych ukarac ${ }^{32}$. W zbliżonym tonie wypowiedziało się 44 profesorów Uniwersytetu Warszawskiego, zwracając się do wszystkich pracowników naukowych, będących posłami i senatorami, aby przeciwdziałali na terenie parlamentarnym poniewieranej godności ludzkiej i upadkowi moralności, którego najjaskrawszym wyrazem sq nieszczęsne wydarzenia brzeskie ${ }^{33}$. Nie zgadzając się z formą i uzasadnieniem odezwy swoich współpracowników, 14 profesorów UW z prof. Leonem Petrażyckim na czele, wydało własne oświadczenie, w którym domagano się natychmiastowego zbadania sytuacji więźniów osadzonych w Brześciu ${ }^{34}$. Podobnie wielu nauczycieli akademickich reagowało na antysemickie wystąpienia studentów-wszechpolaków, ostro wypowiadając się przeciwko próbom wprowadzania w uczelniach ,getta ławkowego". Pod koniec $1935 \mathrm{r}$. profesorowie Politechniki Lwowskiej potępili wystąpienia przeciwko mniejszości żydowskiej. Dwa lata później, w październiku, 50 profesorów i docentów różnych uczelni zebranych Warszawie jednogłośnie wypowiedziało się przeciwko oddzielnym ławkom dla Żydów i zapowiedziało podjęcie wszelkich działań, aby zapobiegać takim sytuacjom w przyszłości, zaś w grudniu tego roku profesorowie Uniwersytetu Warszawskiego, Poznańskiego i Wileńskiego podpisali wspólny apel o przeciwdziałanie wszelkim aktom ograniczania praw obywatelskich ze względu na wyznanie, narodowość czy rasę. W styczniu 1938 r. do protestu dołączyli się uniwersyteccy wykładowcy lwowscy, nie godząc się na uleganie przez senat uczelni terrorowi wprowadzanemu przez młodzież skrajnie prawicową. Z kolei prof. Tadeusz Kotarbiński na znak solidarności z żydowskimi studentami prowadził wykłady, stojąc ${ }^{35}$. W atmosferze niepokojów na uczelniach studenci wszechpolscy napadli na prof. Politechniki Lwowskiej Kazimierza Bartla oraz pobili dziekana Wydziału Humanistycznego Uniwersytetu Warszawskiego prof. Marcelego Handelsmana, natomiast rektor Uniwersytetu Jana Kazimierza we Lwowie prof. Stanisław Kulczyński zrezygnował $\mathrm{z}$ funkcji, sprzeciwiając się $\mathrm{w}$ ten sposób wywieranym na nim naciskom przychylania się do żądań zmierzających do dyskryminacji młodzieży żydowskiej ${ }^{36}$.

32 Brześć-etyka-polityka. Protest profesorów uniwersytetu i politechniki warszawskiej, IR, 1930, nr 351, s. 1.

33 Ibidem.

34 Profesorowie wobec sprawy brzeskiej, IR, 1930, nr 352, s. 1.

35 Profesorowie politechniki lwowskiej poteppiaja gwatty dokonywane na mniejszości żydowskiej, IR. 1935, nr 352, s. 1; Profesorowie przeciwko ghettu, IR 1937, nr 299, s.1; Profesorowie przeciwko ghettu tawkowemu, IR, 1937, nr 353, s. 6; Protest profesorów lwowskich przeciwko ghettu, IR, 1938, nr 21, s. 4; Profesor Kotarbiński wyktada stojac, IR, 1937, nr 298, s. 3.

${ }^{36}$ Brutalny napad na profesora Bartla, IR, 1932, nr 139, s. 1; Echa napadu na profesora Bartla, IR, 1932, nr 141, s. 1; Sprawcy pobicia prof. Handelsmana $w$ areszcie, IR, 1934, nr 78, s. 1; Rektor Kulczyński ustępuje, IR, 1937, nr 299, s. 1. 
Dużym zainteresowaniem łódzkiego dziennika cieszyły się informacje pozyskiwane na temat studentów. Chodziło tu nie tyle o pokazywanie ich codzienności, ale zajmowanie się kwestiami, które odbiegały od powszechnie utrwalonego w ludzkiej świadomości obrazu akademika jako osoby dobrze wychowanej, unikającej złego towarzystwa, przestrzegającej norm życia społecznego, oddanej nauce. Łamy „Ilustrowanej Republiki” zapełniane więc były z jednej strony ukazywaniem ich indywidualnych, nietypowych, czasami trudno akceptowanych zachowań oraz wskazujących na wchodzenie w konflikt z prawem, z drugiej - na bezwzględne manifestowanie swoich poglądów ideowo-politycznych.

Utrata życia przez studentów m.in. Uniwersytetu Warszawskiego, Politechniki Warszawskiej, Uniwersytetu Jagiellońskiego, Uniwersytetu Poznańskiego, Uniwersytetu Wileńskiego, Uniwersytetu Lubelskiego, Akademii Sztuk Pięknych w Krakowie, Wyższej Szkoły Gospodarstwa Wiejskiego w Warszawie, Wyższej Szkoły Rolniczej w Cieszynie stanowiła przedmiot wielu łódzkich doniesień prasowych. Należy stwierdzić, że w pierwszej kolejności śmierć młodzieży akademickiej była konsekwencją popełnianych samobójstw. Powody tych czynów nie zawsze były znane. Zdarzało się, że doprowadził do nich zawód miłosny, jak w przypadku studenta z Warszawy, który w liście pożegnalnym, pisał: Kochać cię nie przestanę nigdy i będę przy tobie zawsze. Żegnaj! ${ }^{37}$, rozpacz spowodowana przedwczesną utratą włosów u studentki filozofii, z której zwierzała się przyjaciółce ${ }^{38}$, rozstrój nerwowy ${ }^{39}$ albo brak jakiegokolwiek oparcia moralnego ${ }^{40}$.

Mężczyźni często pozbawiali się życia strzałem w głowę z rewolweru lub rzucając się pod nadjeżdżający pociąg, kobiety - skacząc z okien wielopiętrowych kamienic albo trując się gazem. W jednym z opisywanych przypadków do samobójstwa doszło po dokonaniu morderstwa na koleżance. Przy okazji przywoływano również krążące w środowiskach uczelniach domniemania o niechlubnym udziale w tych aktach jednego z pracowników szkoły wyższej, który drogą hipnozy wywierał wpływ na studentów, aby bez zwłoki podjęli ostateczną decyzję o swym istnieniu. Zwracano uwagę, że spośród słuchaczy jego wykładów stosunkowo duża liczba młodzieży dokonywała prób samobójczych. Natomiast długotrwała jego nieobecność w pracy zahamowała to zjawisko ${ }^{41}$.

Zdarzały się też nieszczęśliwe wypadki pozbawiające życia studentów. Miały one zwykle miejsce w czasie wakacji lub zimowych ferii. Rejestrowano tragedie rozgrywają-

${ }^{37}$ Samobójstwo studenta, IR, 1928, nr 98, s. 7; Tragiczna miłość młodego studenta, IR, 1931, nr 73, s. 4.

38 Samobójstwo studentki uniwersytetu, IR, 1927, nr 123, s. 7.

39 Samobójstwo studenta $w$ Warszawie, IR, 1929, nr 89, s. 4.

40 Samobójstwo mtodej studentki, IR, 1932, nr 345, s. 5.

${ }^{41}$ Straszliwe samobójstwo studentki, IR, 1929, nr 341, Samobójstwo studenta, IR, 1930, nr 139, s. 5; Samobójstwo studenta $w$ Lodzi, IR, 1930, nr 271, s. 5; Straszne samobójstwo studenta wileńskiego, IR, 1932, nr 324, s. 4; Student zastrzelit studentkę i popetnit samobójstwo, IR, 1936, nr 152, s. 5; Tajemnicze samobójstwa studentów, IR, 1929, nr 206, s. 5. 
ce się w górach, nad morzem, jeziorami i w rzekach, a także podczas jazdy konno czy niefortunnego zjazdu po poręczy w domu akademickim ${ }^{42}$.

Z doniesień „Ilustrowanej Republiki” wynika, że pewna grupa młodzieży akademickiej popełniała czyny niegodne studenta i człowieka, z których obok występków obyczajowych pojawiały się wykroczenia, a nawet ciężkie przestępstwa. Dwóch słuchaczy uczelni okazało się oszustami matrymonialnymi. Student agronomii Uniwersytetu Poznańskiego pomimo wcześniejszych deklaracji i poczynionych wszystkich przygotowań do ślubu zrezygnował w ostatniej chwili z zawarcia związku małżeńskiego. Z kolei przyszły medyk, pobierając od narzeczonej-krawcowej przez wiele lat pieniądze na swoje kształcenie, po ukończeniu edukacji oznajmił, że jego uczucie wygasło i nie wypełni obietnicy poślubienia kobiety ${ }^{43}$. Naganne było również zabranie z użytkowanego lokalu przez studenta Uniwersytetu Warszawskiego maszyny do pisania. Szybko opuszczając dotychczasowe miejsce zamieszkania, w pozostawionym liście informował właścicieli, że jej zwrot nastąpi po całkowitym przepisaniu przygotowanej przez niego pracy naukowej $^{44}$. Niekiedy młodzież akademicka posuwała się do wyłudzeń finansowych, płacąc za akcje czekami bez pokrycia oraz fałszerstw wyroków sądowych w celu uzyskania korzyści majątkowych ${ }^{45}$.

Wskazując na udział studentów w zaborach mienia, łamy gazety ujawniały, że jedni okradali z wartościowych przedmiotów i pieniędzy osoby wynajmujące im pokoje, inni kierowali lub wchodzili w skład złodziejskich band napadających na kantory wymiany walut, w sposób metodycznie przemyślany obrabowywali z biżuterii, futer, bielizny, a nawet narzędzi chirurgicznych mieszkania letniskowe pod Warszawą. W tym procederze nie omijali nawet własnych uczelni, do których dwukrotnie się włamywali. Pierwszym razem jesienią 1939 r., kiedy to z warszawskiej Szkoły Głównej Gospodarstwa Wiejskiego w ciągu kilku dni wynieśli 15 mikroskopów i trzy obiektywy aparatów projekcyjnych oraz cenne instrumenty z prosektorium uniwersyteckiego. Drugim razem, zimą 1938 r. zorganizowana grupa pod przywództwem studenta pochodzącego z zamożnej rodziny ziemiańskiej ukradła z pomieszczeń SGGW 14 mikroskopów. Uczyniła to, wykorzystując wiedzę na temat rabunków zawartą w scenariuszach filmowych ${ }^{46}$.

${ }^{42}$ Studentki zginęly w Tatrach, IR, 1928, nr 232, s. 5; Dwaj studenci utonęli w Jastarni podczas jazdy kajakiem, IR, 1932, nr 233, s. 2; Trzech studentów utonęło w Horyniu, IR, 1933, nr 198, s. 3; Student i uczeń utonęli, IR, 1935, nr 126, s. 3; Tragiczna śmierć studenta na wywczasach pod Łodzia, IR, 1931, nr 224, s. 6; Tragiczna śmierć studenta $w$ krakowskim domu akademickim, IR, 1938, nr 16, s. 3.

${ }^{43}$ Student uciekt przed ślubem, IR, 1933, nr 225, s.3; Student przyrzekt, że się ożeni, IR, 1937, nr 356, s. 7.

${ }^{44}$ Ukradt $w$ celach naukowych, IR, 1934, nr 301, s. 6.

${ }^{4}$ Dwaj studenci oszuści skazani zostali na 2 lata więzienia, IR, 1927, nr 283, s. 4; Student prawa sfatszowat podpisy, IR, 1927, $\mathrm{nr} 111$, s. 8.

${ }^{46}$ Student-bandyta skazany na bezterminowe ciężkie więzienie, IR, 1926, nr 269, s. 2; Student na czele bandy złodziejskiej, IR, 1930, nr 295, s. 3; Student członkiem szajki złodziejskiej, IR, 1932, nr 10, s. 2; Studenci okradali uczelnie, IR, 1937, nr 324, s. 5; Student okradat wyższa uczelnię, IR, 1938, nr 47, s. 5. 
Wreszcie łódzki dziennik skrzętnie przekazywał wiadomości o najcięższych przestępstwach, będących udziałem słuchaczy uczelni wyższych. Pisano o nieumyślnym pozbawieniu życia przez studenta warszawskiego Uniwersytetu swojej 16-letniej koleżanki, która znalazła się w zacienionym miejscu, na linii strzału oddawanego do agresywnego psa oraz głośnym zabójstwie dokonanym przez studenta prawa, który zastrzelił swoją narzeczoną - tancerkę w garderobie teatru „Ananas” w Warszawie. Zdawano relacje o czynie zabicia własnej matki przy użyciu pistoletu przez studenta szkoły wyższej H. Wawelberga i Rotwanda, a także morderstwie na tle rabunkowym służącego doktora medycyny Uniwersytetu Jagiellońskiego Józefa Nussenfelda przez kilku młodych ludzi, wśród których było dwóch studentów Akademii Sztuk Pięknych ${ }^{47}$.

Blisko jedną trzecią wszystkich artykułów podejmujących problematykę szkół wyższych i środowisk akademickich stanowiły relacje, a niekiedy szczegółowe sprawozdania, z których wynika, że w dwudziestoleciu międzywojennym uczelnie stały się ,areną”, na której ścierały się różne ideologie polityczne i wywodzące się z nich negatywne nastawiania do ,innych”. Zjawisko to nie miało spokojnego, pokojowego charakteru argumentowania własnych racji, a wyrażało się zawsze burzliwie w postaci manifestacji i wieców, przeradzających się zwykle w bójki i krwawe walki uliczne lub rozruchy na terenie uczelni. Już same tytuły artykułów zamieszczanych w łódzkim dzienniku wskazują na ich przebieg i zasięg. Oto niektóre z nich: Zajścia na terenie Uniwersytetu Warszawskiego, Bójki studentów w Warszawie po wiecu endeckim, Awantury endeckie we Lwowie, Bójka na Uniwersytecie Jagiellońskim, Starcia policji ze studentami we Lwowie, Krwawe ekscesy studentów w Warszawie, Ekscesy studentów we Lwowie $i$ Wilnie, Echa zajść na Politechnice Lwowskiej, Znów zajścia na wyższych uczelniach, Krwawe zajścia w Szkole Głównej Handlowej, Zajścia w szkole im. Wawelberga i Rotwanda. Do podobnych sytuacji dochodziło również na Politechnice Warszawskiej i w Szkole Głównej Gospodarstwa Wiejskiego w Warszawie. U podłoża tych zamieszek leżały nastawienia antyżydowskie młodzieży wszechpolskiej, a później w latach 30. XX w. związanej z Obozem Narodowo-Radykalnym. Podstawową kwestią było dla nich wprowadzenie na polskich uczelniach numerus clausus, ograniczające przyjęcia Żydów na studia oraz ustanowienie „getta ławkowego”, wymagające od studentów tej narodowości zajmowania oddzielnie wyznaczonych miejsc. W przekazie gazety do starć dochodziło w przypadkach napadów studentów skrajnie prawicowych na młodzież żydowską, obrony własnych praw przez tę mniejszość narodową, a także kiedy polska młodzież o innych orientacjach politycznych występowała w obronie swych kolegów Żydów. Skutkiem zamieszek, które kończyły się nierzadko ingerencją policji, aresztowaniem najbardziej aktywnych uczestników zajść, wielokrotnym zamykaniem uczelni lub zawieszaniem wykładów, było najczęściej wielu rannych. Ponadto swoje niezadowolenie słuchacze wyrażali, organizując strajki. Jedni

47 Student zabił koleżankę, IR, 1929, nr 293 [wł. 294], s. 4 i 1930, nr 4, s. 7; Student zastrzelił artystkę $w$ teatrze, IR, 1931, nr 214, s. 1; Student zastrzelit tancerke, IR, 1932, nr 117, s. 5; Student zabil matkę, IR, 1932, nr 114, s. 2; Studenci Akademii Sztuk Pięknych-mordercami, IR, 1934, nr 139, s. 1. 
czynili to na znak solidarności ze społecznością żydowską, inni w obronie zatrzymanych przez władze porządkowe kolegów, domagających się wyznaczania oddzielnych ławek dla Żydów. Zdarzało się na przykład, jak to miało miejsce w przypadku Poznania, że studenci niszczyli sklepy żydowskie i wybijali szyby w oknach tamtejszej synagogi, albo kiedy w Warszawie grupa studentów-oenerowców z Uniwersytetu, Politechniki i SGH po wtargnięciu na wykład w WWP wzywała młodzież polską, aby stanęła w szeregach walki o „getto ławkowe”, a słuchaczy Żydów siłą zmusiła do zajęcia miejsc po lewej stronie sali $^{48}$.

Wspomniane wypadki miały miejsce w mniejszym lub większym nasileniu przez cały okres dwudziestolecia międzywojennego z niewielkimi tylko przerwami. W styczniu 1938 r. „Ilustrowana Republika” zamieściła apel ogólnego zebrania profesorów Politechniki Lwowskiej do młodzieży akademickiej, aby powstrzymała się od dalszej eskalacji napięć. Czytamy w nim: Wyższe uczelnie stanowić winny w każdym narodzie ognisko jego myśli $i$ wysilków badawczych niezależnie od jakichkolwiek wpływów życia politycznego. Naruszenie tego prawa godzi w najistotniejsze zdobycze kultury spotecznej. W życiu lwowskich uczelni akademickich nadszedt dzień, gdy szczera troska o polskie jutro zmusza zebranie ogólne profesorów do przypomnienia młodzieży tych starych prawd, które deptane sq $w$ dziwnym niezrozumieniu następstw tego kroku. [...] Nie możemy przemilczeć $i$ silnie nie napiętnować metod, jakimi pewna część młodzieży postuguje się $w$ osiaganiu swych zamierzeń i celów. Wypadki dzikich w swych przejawach napadów na pojedynczych studentów na terenie szkoły budza odrazę, a brak reakcji ze strony większości młodzieży na te niegodne akademickiego honoru fakty budzi w nas stale wzrastające

${ }^{48}$ Ze względu na pokaźną liczbę artykułów poświeconych tej problematyce zostaną przywołane tylko niektóre z nich. Zob. np. Nowe zajścia $w$ Krakowie, IR, 1929, nr 341 [wł. 314], s. 1; Zajścia na terenie Uniwersytetu warszawskiego, IR, 1928, nr 324, s. 1; Bójka na Uniwersytecie Jagiellońskim, IR, 1928, nr 285, s. 3; Starcia policji ze studentami we Lwowie, IR, 1929, nr 68, s. 1; Awantury studentów we Lwowie, IR 1929, nr 154, s. 1; Echa wypadków lwowskich, IR, 1929, nr 150, s. 1; Walki na ulicach Lwowa, IR, 1929, nr 156, s. 1; Skandaliczne zajścia w Poznaniu, IR, 1929 s. 156, s. 1; Uniwersytet krakowski zamknięty, IR, 1931, nr 297, s. 3; Ekscesy antyżydowskie studentów w Warszawie, IR, 1931, nr 302, s. 1; Zajścia w uniwersytecie w Wilnie, IR, 1931, nr 303, s. 1; Wniosek endecji o numerus clausus na wyższych uczelniach, IR, 1932, nr 64, s. 1; Zawieszenie wykładów na politechnice lwowskiej, IR, 1932, nr 142, s. 1; Wystapienia antysemickie studentów, IR, 1932, nr 143, s. 1; Nowe ekscesy studentów endeckich, IR, 1933, nr 38, s. 2; Awantury na Uniwersytecie Warszawskim, IR, 1933, nr 54, s. 1; Zawieszenie wykładów na SGGW i Politechnice Warszawskiej, IR, 1933, nr 314, s. 2; Zawieszenie wykładów na Uniwersytecie Warszawskim, IR, 1934, nr 74, s. 1; Zajścia na uniwersytecie $w$ Krakowie, IR, 1943, nr 313, s. 1; Burdy studenckie na wyższych uczelniach we Lwowie $i$ Krakowie, IR, 1935, nr 315, s. 4; Zajścia antyżydowskie w Warszawie, IR, 1935, nr 315, s. 4; Wyższe uczelnie będą nadal zamknięte, IR, 1935, nr 329, s. 1; Zajścia n Politechnice Warszawskiej, IR, 1936, nr 122, s. 1; Awantury antyżydowskie we Lwowie, IR, 1936, nr 148, s. 1; Bójki na wyższych uczelniach, IR, 1937, nr 15, s. 1; Awantury na uczelniach trwają, IR, 1937, nr 16, s. 1; Strajk studentów we Lwowie i Poznaniu, IR, 1937, nr 20, s. 3; Znowu zajścia na wyższych uczelniach, IR, 1937, nr 49, s. 4; Zajścia na Wolnej wszechnicy w Warszawie, IR, 1937, nr 309, s.2; Zajścia na wyższych uczelniach, IR, 1938, nr 20, s. 3; Zajścia w szkole im. Wawelberga i Rotwanda, IR, 1938, nr 80, s. 3; Dalsze zajścia na wyższych uczelniach, IR, 1938, nr 331, s. 2; Ghetto na akademii stomatologicznej, IR, 1939, nr 15, s. 5; Wiec akademicki we Lwowie, IR, 1939, nr 43, s. 4; Starcia między studentami $w$ Warszawie, IR, 1939, nr 63, s. 3. 
zaniepokojenie, o tę młodzież, która w przyszlości jako oświecona część spoteczeństwa ma do spetnienia tyle kulturalnych i szczytnych zadań dla państwa ${ }^{49}$.

$\mathrm{Z}$ relacji gazety wynika, że środowisko lwowskie było jednym z miejsc, gdzie wystąpienia przeciwko mniejszości żydowskiej przybierały nader drastyczny charakter. Odezwa profesorów nie spotkała się z jakimkolwiek oddźwiękiem ze strony osób, do której była kierowana. W dalszym ciągu dochodziło do bójek i napaści na Żydów, powodujących ich ciężkie obrażenia. W marcu 1939 r. policja przeprowadziła rewizję w Domu Akademickim, Domu Techników i Domu Medyków, gdzie napotkała silny opór ich mieszkańców. W wyniku przeszukiwań znaleziono znaczą liczbę broni palnej, broni do walki wręcz i spore ilości materiałów wybuchowych. Aresztowano też 86 studentów. W maju tego roku doniesiono o zamordowaniu na terenie Politechniki studenta chemii Markusa Landaua ${ }^{50}$. Wydarzenie to spowodowało przekazanie na ręce rządu, Sejmu i Senatu memoriału profesorów wyższych uczelni we Lwowie z prof. Kazimierzem Bartlem na czele, w którym pisano: Uczelnie wyższe we Lwowie sa od szeregu lat widowniq krwawych ataków gwattu uprawianych pod hasłami nacjonalizmu i antysemityzmu. $\mathrm{Na}$ silenie i brutalność tych zajść wzrasta z każdym miesiqcem. [...] W roku bieżacym byliśmy świadkami pierwszego zabójstwa, a w ostatnich miesiacach zanotowano dwa dalsze wypadki zbrodni noszace wszelkie znamiona uplanowanego i skrytobójczego mordu ${ }^{51}$. Ze względu na fakt, że wiele stowarzyszeń akademickich Politechniki Lwowskiej nie zajęło wobec zachodzących sytuacji jednoznacznego stanowiska, minister WRiOP zawiesił działalność $18 \mathrm{z}$ nich ${ }^{52}$.

W nawiązaniu do przedstawionych wyżej informacji należy przypomnieć, że w latach międzywojennych również w wielu państwach europejskich młodzież akademicka urządzała wiece i wychodziła na ulice. Zdarzało się, że „Ilustrowana Republika” przywoływała dane na ten temat, wskazując jednocześnie na powody publicznych wystąpień. W Pradze, rumuńskiej Jassy i Bukareszcie miały charakter antyżydowski z żądaniem wprowadzenia numerus clausus, w Budapeszcie i Szegedzie dochodziło do rozruchów antysemickich, w Berlinie walczono o usuniecie Żydów z uczelni, w Gandawie występowano przeciwko flamandyzacji uczelni, w Atenach domagano się zmniejszenia opłat za studia, w Londynie „hucznie świętowano” wydarzenia historyczne z 1605 r., w Zagrzebiu przyczyną niepokojów stawały się różnice w poglądach politycznych studentów, w Madrycie protestowano przeciwko utworzeniu nowej konkurencyjnej wyższej szkoły odentologicznej w Walencji, w Paryżu domagano się odsunięcia od wykładów profesora ustawodawstwa finansowego, w Wiedniu protestowano przeciwko wydłużeniu nauki na

49 Apel profesorów do młodziė̇y akademickiej, IR, 1938, nr 26, s. 3.

${ }^{50}$ Aresztowanie 68 studentów we Lwowie, IR, 1939, nr 71, s. 1; Pogrzeb zamordowanego studenta, IR 1939, nr 147, s. 3; Co się dzieje na Politechnice Lwowskiej, IR, 1939, nr 148, s. 3.

${ }^{51}$ Przeciw anarchii na wyższych uczelniach, IR, 1939, nr 162, s. 2.

${ }_{52}$ Zawieszenie 18 stowarzyszeń studenckich na Politechnice Lwowskiej w zwiąku z ostatnimi zajściami, IR, 1939, nr 164, s. 5. 
fakultecie medycznym o dwa semestry. Wydarzenia te jasno pokazują, że studenci oprócz tego, że pragnęli zabezpieczyć swoje prawa, angażowali się w rozgrywki polityczne, a spora część ulegała ideologii nacjonalistycznej ${ }^{53}$.

Podsumowując, należy podkreślić, że treści zamieszczane na łamach „Ilustrowanej Republiki”, choć dają pewien obraz szkolnictwa wyższego i środowiska akademickiego w dwudziestoleciu międzywojennym, to jest on zdecydowanie wybiórczy. Do rzadkości należały opisy przybliżające działalność merytoryczną uczelni i zaangażowania ich społeczności w proces studiowania. Nie można się zresztą temu dziwić, gdyż dziennik ten koncentrował się w szczególności na kwestiach dla jego redaktorów priorytetowych, a więc wydarzeniach ze świata nauki w Łodzi, co owocowało szeregiem artykułów poświęconych próbom budowania „miasta akademickiego”, oraz na tym, co mogło najbardziej zaciekawić czytelników, czyli niecodziennymi zachowaniami profesury i studentów.

Artykuł ten można traktować jako monografię problemu podejmowanego w konkretnym tytule prasowym, także jako dowodu, że czerpanie wiedzy z periodyków pozwolić może na dotarcie do takich informacji, które trudno odnaleźć w innych źródłach, wreszcie jako ukierunkowującą bazę materiałową do dokonywania szerszych syntez dotyczących szkolnictwa wyższego w Polsce w czasach przeszłych.

\section{Bibliografia}

Źródła drukowane

„Ilustrowana Republika” 1925-1939.

\section{Opracowania}

Hrycek M., Stosunki w tódzkiej prasie okresu międzywojennego. Polemika prasowa na tamach tódzkich dzienników na przykładzie „,Głosu Polskiego” i koncernu Republiki, „Folia Litteraria Polonica” 2011, nr 1.

\footnotetext{
53 Zob. np. Studenci czescy żądają wprowadzenia „,numerus clausus” dla cudzoziemców, IR, 1929, nr 315, s. 3; Zamkniecie uniwersytetu w Pradze, IR 1929, nr 318, s. 1; Nowe zaburzenia studentów w Pradze, IR, 1929, nr 321, s. 1; Strejk studentów w Jassach, IR, 1929, nr 350, s. 3; Krwawe walki z policją. Uniwersytet w Bukareszcie zostat zamknięty, IR, 1932, nr 85, s. 1; Krwawe starcia policji ze studentami. Demonstracje w Budapeszcie i Szegedynie, IR, 1935, nr 322, s. 2; Krwawe zajścia na uniwersytecie w Berlinie, IR, 1932, nr 180, s. 1; Awantury studenckie $w$ Atenach, IR, 1929, nr 329, s. 1; Walka studentów z policja na ulicach Londynu, IR, 1930, nr 305, s. 3; Strejk studentów w Zagrzebiu, IR, 1933, nr 61, s. 2; Strejk studentów w Madrycie, IR, 1932, nr 101, s. 2; Awantury na uniwersytecie $w$ Paryżu, IR, 1936, nr 65, s. 4; Demonstracje studentów w Wiedniu trwaja, IR, 1937, nr 329, s. 4.
} 
Maj S., Studia geofizyczne w Wolnej Wszechnicy Polskiej w Warszawie 1918-1939, „Przegląd Geofizyczny" 2013, nr 3-4.

Michalska I., Sprawy szkolnictwa nauczycieli i uczniów w tódzkim dzienniku „Ilustrowana Republika” w latach 1925-1939, „Przegląd Historyczno-Oświatowy” 2017, nr 3-4.

Michalska I., Życie łódzkich rodzin w czasach kryzysu ekonomicznego lat trzydziestych XX wieku w przekazie gazety „Ilustrowana Republika”, „Wychowanie w Rodzinie” 2016, nr 2, t. XIV.

Paczkowski A., Prasa polska w latach 1918-1939, Warszawa 1980.

Przegląd prasy łódzkiej, „Ilustrowana Encyklopedia Historii Łodzi”, br. r. wyd., nr 9.

Skład osobowy i spis wykładów na rok akademicki 1936/37, Łódź, nakładem Wolnej Wszechnicy Polskiej, Oddziat w Łodzi, 1936.

Władyka W., Prasa Drugiej Rzeczypospolitej, w: J. Łojek, J. Myśliński, W. Władyka, Dzieje prasy polskiej, Warszawa 1988. 